\title{
GREED IN HAMKA'S NOVEL MERANTAU KE DELI
}

\author{
Pardi \\ Universitas Islam Sumatera Utara, Medan, Indonesia \\ pardi@sastra.uisu.ac.id
}

Received: 01/07/2021

Accepted: 25/07/2021

Publication: 01/08/2021

\begin{abstract}
Merantau ke Deli is a novel written by Hamka published in 1939. The main theme of this novel is about Minangkabaunese culture and the conflict in the marriage of Leman, a Minangkabaunese, and Poniem, a Javanese. Adat law makes Leman married Mariatun, a Minangkabaunese as his second wife. The focus of this study is on the act of Greed performed by Leman and Mariatun. This is descriptive qualitative research based on Miles, Huberman, and Saldana (2014). The theory of Greed stated by Kets De Vries (2016) was used to analyze the data obtained. The results show two kinds of Greed in the novel; the Greed for the woman's beauty and the Greed for poverty. Leman performs the Greed on the woman's beauty to marry Poniem, although it is forbidden for Minangkabaunese man to marry a non-Minangkabaunese woman. Poniem's beauty makes him break the adat law. The greediness of beautiful woman also happens when he meets Mariatun, a beautiful young woman from the Minangkabaunese tribe. The greediness on poverty showed by Mariatun for taking the batik and also for dominating Leman's poverty. However, the acts of Greed performed by the characters in the novel create tragic flaws in their future life.
\end{abstract}

Keywords - adat law, greed, beauty, poverty, marriage, minangkabaunese

\section{Introduction}

Almost every human being feels emptiness and meaninglessness at one point in their life. Human beings are like to make an effort to fill the emptiness and meaninglessness without realizing its futility, and being stuck in it unconsciously is Greed. Greed cannot be eradicated from human nature. Greed is something that can be found in all human communities. Human beings seek to enrich themselves (Melleuish, 2009: 23). Greed refers to the strong desire owned by someone for something such as money, power, possessions, love, etc. than needed. A person becomes greedy when he wants something strongly. Greedy people usually have no integrity, no genuine love of anyone, and no genuine friend around. Greediness is often portrayed in literary works. Most of the greediness shown in literary works is on poverty, power, and other possessions. It is relevant to what Manugeren, Suhadi \& Pardi (2020: 152) stated that poverty could trigger crime, and crime can disrupt the comfort and security of many people even to the problem of violence in the household. However, an act of being greedy is also shown in Merantau ke Deli, a novel written by Hamka.

The novel talks about a Javanese woman, Poniem, who is wandering in Tanah Deli. She becomes a concubine. A young Minangkabaunese man, Leman, fell in love with her. He did not care about the rules he must keep as a Minangkabaunese man as long as he married Poniem. He also married Mariatun, a Minangkabaunese woman, to be his second wife after returning from his village in Minangkabau. Mariatun is a beautiful young girl with bad manners. His second marriage created a disaster in her family life with Poniem. The greediness is shown by the 
protagonist, Leman, and also Mariatun. Leman was greedy for women.

Meanwhile, Mariatun is greedy about the property. This is a fascinating topic to be a moral lesson in our daily life. Greed is such a destructive manner. Greediness shown by Leman and Mariatun creates disaster not only in their life but also in other people. How Greed can destroy people will be the primary purpose of this study.

\section{Literature Review}

Greediness will not get enough of something and will always seek new ways to get more of their favored things to be kept themselves. Greediness is one of the harmful human acts that can destroy himself, even society. Sometimes, some people can commit atrocious acts and completely lack morality to gain their goals more. Kets De Vries (2016: 9) states that Greed has been named one of the seven fundamental character flaws or "dark" personality traits plaguing humankind. In the sixth century, Pope Gregory the Great drew up this list of transgressions that were seen as fatal to spiritual progress. He was not the only one concerned about this flaw; Greed has been condemned since time immemorial, as it undermines the fairness on which the welfare and stability of the community are built. From his point of view, it can be said that Greed is very dangerous for everyone that can harm themself and also the community from which they come.

According to Boro (2019: 1012), Greed is an intense and selfish desire for something, especially wealth, power, or food. It means that Greed is a desire to gain something that is not necessary for own survival. Something is not enough. The more they attain, the more he wants. No satisfaction was met. Horlick (2009: 20) states that Greed is a big subject that can once be seen as a disease at the heart of society and a motivating force behind the progress of humankind. When a man has the purpose of the materials they want to have, the ambition to obtain them is enormous and often leads to the Greed of human self-control.

Relevant to the meaning of Greed stated by experts above, Baba (1967) claims that Greed is a state of restlessness of the heart, and it consists mainly of craving for power and possessions. Ilyas and Purwarno (2019: 110) conclude that Greed is one of the bad manners that draw various evil and sins. It is a selfish, excessive, or uncontrolled desire to possess or pursue money, wealth, food, or other possessions, especially when this denies the same good to others. In their article in Scientific American Mind, Arely, Gruneisen, and Ritter (2013: 794) see Greed as consuming desire for wealth or affluence, causing one to think of else were.

Kets De Vries (2016: 19-20) states that the indicator of the greed syndrome is (1) overly self-centered behavior is the first giveaway, (2) envy (an extreme desire to get what belongs to others), and Greed (an excessive desire for possessions such as wealth and power) are like twins, (3) greedy people struggle with the concept of empathy, (4) greedy people look at the world as a zero-sum game, (5) greedy people are highly talented in taking things that don't belong to them including the credit for work done by others, (6) greedy people thing short term commonly blind to how costly their actions may be in future, (7) greedy people are not good at maintaining boundaries, and (8) greedy people are never satisfied with what they have.

Greedy people must consciously realize their choice on the other ways of living and what they act or do. The inner thoughts, feeling, impulses, perceptions, and needs must be the attention of greedy people in learning that life is not merely about holding onto the thing.

\section{Research Method}

This research paper is fundamentally based on documentary research with Merantau ke Deli by Hamka as the primary source of information. Other literary works and some scientific articles dealing with Greed's issue and interviews are used to support the analysis. This is research conducted using descriptive qualitative methods by Miles, Huberman, and Saldana (2014) to discuss social phenomena in which the focus goes to Greed. The data from interviews were used to find out that Greed is dealing with society. Data trustworthiness is 
tested by triangulation.

\section{Results and Discussion}

Merantau ke Deli, written by Hamka, is a novel published in 1939. The central theme of the novel is the custom of Minangkabau. A Minangkabaunese man will be considered lowly when he marries a non-Minangkabaunese woman. The story against the concept. This novel tells about a mixed marriage between a Javanese woman, Poniem, and a minangkabaunese man, Leman. They married against the adat law. They live together for many years without a child born. The Greed of the protagonist, Leman, is shown from the beginning of the story. The story also tells about the characters' Greed for possessing poverty and women's beauty, as described below.

\section{Greed on Woman's Beauty}

The protagonist Leman in the novel shows Greed for women's beauty in the novel since the beginning of the story. He even against his adat law to marry Poniem, a Javanese woman. The adat law slightly forbids this concept. Children born from this marriage will not be considered as Minangkabaunese. However, Leman does not care about this law. The most important thing on his mind is to marry Poniem. Poniem is a concubine of the supervisor in the tea plantation in Tanah Deli. They fall in love with each other when Leman sells his stuff on the plantation. He is amazed by the beauty of Poniem. He asked Poniem to meet him one night and proposed to her. He even does not listen to his friends not to marry her. This can be considered as Greed for a woman's beauty. In this context, his feeling for Poniem is based on her beauty since he fell in love at first sight. The following quotation shows Leman's Greed.

Yang menarik hatinya ke kebun ialaha seorang perempuan yang cantik, masih muda. Dia istri "piaraan" dari "mandor besar". Barang emasnya banyak, ringgit pun bersusun di dadanya, bergelang kaki pula selain gelang tangan, dan berkalung ringgit. (Hamka, 1982: 5)

The meaning of the quotation above is what makes Leman trade in the plantation as a beautiful young woman. She is a mistress of a great supervisor of the plantation. She has many gold jewelry. From the quotation above, it can be seen that Leman falls in love with the woman because of her beauty. As portrayed in the quotation below, his greediness for beauty makes him forget about the risk for himself and his friends.

Tetapi anak muda itu telah lupa daratan, dia lupa bahwa dia orang luar, orang pereman; dia lupa bahwa kalau langkahnya terdorong kepada kuli itu, bukan dia saja akan tercela atau terusir dari kebun itu, teman-teman sekampungnya yang sama-sama berdagang di sana pun akan diusir pula. ... Banyak kawan-kawannya Leman yang memberi pandangan kepadanya, bahwa perbuatan itu salah benar, salah pada pandangan orang di kampung dan merusakkan kawankawan yang masih tinggal di kebun itu, sebab boleh jadi mandor besar melepaskan dendamnya kepad amereak dengan mengusir mereka dari sana. (Hamka, 1982: 6, 21)

The meaning of the quotation above Leman is to be delirious on Poniem. He forgot that he was an outsider. He also did not aware that what he did would affect his friends also. They can be expelled to trade goods on the plantation. However, his greediness for the beauty of Poniem is a trigger on his unlucky life in the future.

It is an instinct that a man loves the woman's beauty. Human beings are social creatures. They need other people to live. The custom of the society he lives in should be considered before marrying what Leman collides with the adat law of Minangkabau, to which community he belongs.

In the story, Leman also married Mariatun as his second wife. Mariatun is a young Minangkabaunese who comes from the same village as Leman in Minangkabau. Leman felt for Mariatun when he came back to his village with Poniem. It is a tradition that when a Minangkabaunese man succeeds in merantau, he must come back to the village to show his success. As a minangkabaunese man, he is suggested to marry at most minuscule a minangkabaunese girl to follow the adat. His Greed for the woman's beauty raises when the 
elder shows him Mariatun. His desire to marry Mariatun, a beautiful young woman from the same tribe as he appears. He never thought it would be a disaster in his marriage with Poniem and become his long-lasting regret. In the name of fulfilling his responsibility on adat law, he decides to marry Mariatun. He never thought about Poniem's feelings. The quotation below shows how greedy Leman is for the woman's beauty.

Rupanya tidak kalah dengan perempuan-perempuan lain. Sutan Paduko memperlihatkan potret anak perempuan itu, yang mulai saja dilihat oleh Leman, hatinya sudah tergerak.... Tidak berapa jauh daripadanya berdiri seorang perempuan agak tua berdekatan dengan seorang anak gadis cantik, sehat dan bersih, badannya tegap semampai, matan=nya agak besar dan hitam, alisnya seraut jatuh, berdiri melihat orang akan berangkat. Leman melihat ke sana, pandang bertemu pandang, dada berdebar dan dia gugup, gadis itu tertekun dan tak kuat memandang mata Leman. (Hamka, 1982: 53, 54)

The meaning of the quotation above is that Mariatuan is as beautiful as other women. Sutan Paduka showed the picture of Mariatun. Leman fell in love with the beauty of the girl. A somewhat older woman is standing with a beautiful young girl when Leman leaves his village. Leman gazed at the beautiful young woman. They were glazing at each other. It means that Leman has felt the beauty of the beautiful young woman. He did not remember that he was a married man. His Greed for the beauty of the woman has blinded his heart. The quotation below shows more about his Greed for the beauty of Mariatun.

Sesaat kemudian dia memandang pula ke atas, maka lupalah dia kepada perempuan yang tidur di sampingnya itu, terbayang pula kembali keindahan hidup yang akan datang, duduk bersanding dengan perempuan yang lebih cantik, lebih jelita. (Hamka, 1982: 56)

The meaning of the quotation above was when Leman was in the bedroom with his wife, Poniem, she only thought about Mariatun. Even when his wife slept beside him, the imagination about his wonderful future life for marrying the beautiful woman is in his mind. The Greed on the woman's beauty in Merantau ke Deli shows that woman's beauty creates tragic flaws for men. It is an instinct that a man loves beauty. But, they need to make it rational that it will not affect their future life.

\section{Greed on Poverty}

Every human being has greediness in their life. His goal of life is never fulfilled. They want more and more in poverty, power, and other possessions. Greed on poverty will create a wild manner as possessed by an animal. The greediness of poverty is also portrayed in Merantau ke Deli by Hamka. Hamka himself portrayed Mariatun as a Greed woman in poverty as if he wanted to criticize all minangkabaunese women. As a tribe that adheres matrilineal system, the Minangkabaunese woman has an enormous role in her family's poverty. The acts of Greed shown by Mariatun are portrayed after her marriage to Leman. As a wife from the same tribe as Leman, her husband, she looks down on Poniem. She never thought that what Leman has now is because Poniem sold her gold jewelry given by the supervisor of the tea plantation. Money gained from selling her jewelry is used as the capital for Leman's merchandise trade. Mariatun shows her greediness in poverty by taking a good batik for herself. See the following quotation.

Baru saja peti itu terbuka, datanglah mariatun mendekati. Hatinya tertarik benar melihat sehelai kain batik yang halus. Belum lagi dihitung dan dilihat faktur barang itu, kain tersebut telah dihelakannya. "Ini buat saya." Katanya dengan senyum, lalu hendak dilarikannya ke atas loteng. "Jangan, tunggu dulu, fakturnya belum diperiksa." Kata Leman. (Hamka, 1982: 104)

The quotation above means that the box is opened for a while, and Mariatun comes closer to the box. She is interested in a soft batik in the box. Although it has not been counted the price, she took the batik for herself. Smiling, she said that the batik was for her. She tried to take the batik with her to her room. Leman tried to prevent what Mariatun did, but she did not care. The batik is merchandise that should be sold at their shop. The price of the batik itself has not been noted in the journal book. This act of Greed is relevant to what Kets De Vries (2016: 20) stated that greedy people are highly talented in taking things that don't belong to them, including the credit for work done by others. Mariatun takes something doest not belong to her. 
The Greed on poverty is also shown by Mariatun when Leman asks her to live with him and Poniem in the same house. The quotation below proves her Greed for poverty.

Padahal kalau tidak diturutinya sekarang, tentu dia akan rugi. Apalagi ibunya membisikkan lebih baik kehendak suaminya itu dituruti, supaya dia pun ikut pula memperhatikan perniagaan dan berkuasa pula atas harta benda suaminya. Jangan sampai "orang lain" itu saja yang beroleh laba dan keuntungan sebagaimana selama ini. (Hamka, 1982: 92)

The quotation above means Mariatun must follow her husband's will to live under one roof with Poniem. She will lose for not following his wish. And also, her mother told her that she should live together with Poniem to make her pay attention to the shop and have power in her husband's poverty. She does not want Poniem only to get advantages so far. This is genuinely a kind of greediness on poverty. She never thought that what Leman has now is because Poniem helped him before. His husband's trade will never be as successful as now if Poniem did not sell her gold jewelry to be the trade's capital.

\section{Conclusion}

Every person has a greedy manner in their life. It can be Greed on power, poverty, or other possession. Greed creates tragic flaws for the one who possessed it and also for people around them. There are two kinds of Greed in the novel: Greed for a woman's beauty and Greed for poverty. The act of Greed on the woman's beauty in the novel performed by Leman as the male protagonist has created an ominous future in his life. His greediness for women's beauty makes him break the adat law of the community where he belongs. His second greediness on woman beauty is toward Mariatun, a beautiful young woman from his village. Without regard to Poniem's feelings, he decided to marry Mariatun. He felt for Mariatun at first sight. Mariatun's bad attitudes create tragedy in his marriage with Poniem. He finally divorced Poniem.

Meanwhile, greed on poverty is portrayed by Mariatun. She is greedy to have control of Leman's poverty. She never considered the poverty is also Poniem's.

\section{References}

Kets de Vries, Manfired F.R (2016). The Greed Syndrome. INSEAD Working Paper, No. 2016/26/EFE. https://papers.ssrn.com/sol3/papers.cfm?abstract_id=2766233

Boro, Alidon Razakon Ibourahima. 2019. The Other Sides of Greed through The Character of Moll in Moll Flanders By Daniel Defoe: A Life Lesson For All. Journal of Advances in Social Science and Humanities, 5 (8), 1011-1016 (2019).

Horlick, Nicole. (2009). Greed. Palgrave: Macmillan.

Baba, Meher (1967). Discourses, Volume II. Sun Fransisco: Sufism Reoriented.

Ilyas, Wand Prayoga \& Purwarno (2019). Greed in Jeanne Duprau's Novel The Citi of Ember. Journal of Language, 1 (2), page 101-111.

Dan Ariely, Aline Grüneisen, and John Ritter (2013). The Price of Greed. Scientific American Mind, 24(5):38-42

Hamka. (1982). Merantau ke Deli. Cetakan VIII Jakarta: Pustaka Panjimas.

Manugeren, M. Jumino Suhadi \& Pardi Pardi. (2020) Literature as a Medium of Exposing Social Problem through Thomas Gray's "Elegy Written in A Country Churchyard". Journal of Language and Literature, Vol. 20 No. 01 - April 2020, 150-158.

Melleuish, Greg. (2009). Greed is great. IPA Review. 23-24. 